\title{
Kentlerde Yeni Yerleşim Alanlarının Gelişimi ve Katı Atık Sorunu: İzmit- Yahyakaptan Mahallesi Örneği
}

\author{
Kazım Onur Demirarslan ${ }^{1 *}$, Deniz Demirarslan² \\ ${ }^{1}$ Artvin Çoruh Üniversitesi, Mühendislik Fakültesi, Çevre Mühendisliği Bölümü, 08100, Artvin. \\ ${ }^{2}$ Kocaeli Üniversitesi, Mimarlık ve Tasarım Fakültesi, İç Mimarlık Bölümü, 41100, Kocaeli.
}

\section{Özet}

Türkiye'de zaman içinde artan nüfus ve diğer gelişmelere bağll olarak yerleşme birimleri büyümüş, gelişmiş ve yayılmıştır. Cumhuriyetin ilanından itibaren Kocaeli ili İzmit ilçesinde sanayinin ve ticaretin gelişmesiyle birlikte yoğun iş göçü yaşanmış ve şehrin nüfusu artmiștır. 1950'li yıllardan bu yana nüfusu hızla artan şehrin en büyük sorunlarından biri konut sorunudur. Devlet ve özel sektör aracılığ ile yapılan konut yerleşimleriyle İzmit ilçesinin nüfus artışına dayalı konut sorunu çözülmeye çalışılmış; ancak 1999 Marmara Depremi ile konut sorunu farklı bir boyut almıștır. 1999 depremi sonrasında bașlatılan çalıșmalar ile İzmit ilçesinde yeni yerleşim alanları belirlenmiştir. Bu yerleşim alanlarının gelișimi 2000 'li yıllardan itibaren hız kazanmıştır. Son yıllarda kentsel dönüşüm uygulamaları da yeni yerleşim alanlarının gelişimini tetikleyici bir unsur olmuştur. Yeni yerleşim alanlarının inşass ile bu alanların hem yüzölçümü hem de nüfusu artmıș, alt ve üst yapı sorunları, çevre sorunları bașta olmak üzere çeșitli sorunlar ortaya çıkmıştır. Gürültü, hava kirliliği, evsel atıklar, görüntü kirliliği yeni yerleşim alanlarında önemli çevre sorunlarını oluşturmaktadır. Bu çalıșma kapsamında İzmit ilçesi Yahyakaptan Mahallesi'nde nüfus artıșı ve yeni yerleșim alanlarının olușum nedenleri ortaya konulacak, konut tipolojileri ile konut kullanım ihtiyacı kıyaslanarak, yeni yerleșim alanının mahalle üzerindeki çevresel etkilerine dair bulgular verilecek ve bölgede artan yapılaşma ve nüfusa göre katı atık miktarı çevre mühendisliği açısından TÜIK (Türkiye İstatistik Kurumu) verileri yıllık atık miktarı hesaplama yöntemlerine göre incelenerek evsel atık sorununa çözümler önerilecektir.

\section{$\underline{\text { Anahtar Sözcükler }}$}

Çevre Kirliliği, İzmit, Kocaeli, Katı Atık, Katı Atık Yönetimi

\section{Development of New Settlement Areas and Solid Waste Problem in Cities: Case Study on Izmit - Yahyakaptan Neighbourhood}

\begin{abstract}
In Turkey settlement units enlarged, developed and spread within time due to increasing population and other developments. Starting from the declaration of Turkish Republic, work immigration occurred to Kocaeli province (Izmit city) together with developing industry and trade and accordingly the population of the city increased. One of the most important problems of the city, population of which rapidly increases since 1950's is accommodation. The accommodation problem was tried to be solved by residents built by state and private sector but residential building problem gained a new dimension after the Marmara earthquake in year 1999. New areas of settlement were determined in Izmit city by the studies initiated after 1999 earthquake. The development of these settlement areas accelerated after 2000's. The urban conversion applications in recent years have also been a triggering effect for the development of settlement areas. Together with the construction of new settlement areas, cross sectional area and population of these areas increased and various problems appeared such as environmental, infrastructure and superstructure problems. Noise, air pollution, domestic wastes and visual pollution constitute the important problems in new settlement areas. Under the scope of this study, reasons of population increase and formation of new settlement areas in Izmit city, Yahyakaptan neighbourhood will be presented, findings about environmental effect of new settlement area on the neighbourhood will be submitted by comparing resident typologies and resident usage requirement and finally solid waste amount according to increasing settlements and population in the region will be examined from environmental engineering point of view, according to TUIK (Turkish Statistics Institution) annual waste amount calculation methods and solutions will be suggested for domestic waste problem.
\end{abstract}

\section{$\underline{\text { Keywords }}$}

Environment Pollution, Izmit, Kocaeli, Solid Waste, Solid Waste Management,

\section{Giriş}

Tarih boyunca barınma gereksinimi, iklim ve topoğrafik koşullar, tarım, sanayi, madencilik, hayvancılık gibi yaşamın devamını sağlayan sektörler yerleşim alanlarının belirlenmesini etkileyen unsurlar olmuşlardır. Dünyanın ilk ve önemli yerleşim alanlarını barındıran Türkiye'de zaman içinde artan nüfus miktarı ve diğer gelişmelere bağlı olarak yerleşim 
birimleri büyümüş, gelişmiş ve yayılmıştır. Bu yerleşmelerin nüfus miktarı, fonksiyonları, yaşam tarzları, idari statüleri ve kültürel düzeyleri de birbirinden farklıdır. Bu yerleşim alanlarından bazıları tarih boyunca varlığını devam ettirerek günümüze dek gelebilmiştir. Bu yerleşim alanlarından biri de Kocaeli ili İzmit ilçesidir.

Bitinya, Roma, Bizans, Selçuklu ve Osmanlı dönemlerinde üzerinde yer alan uygarlıkların tarihi, sosyo-ekonomik ve kültürel katkılarıyla varlığını devam ettiren İzmit şehri 1888 yılında sancak olmuştur. Cumhuriyetin ilanından itibaren Türkiye'nin önemli sanayi şehirleri arasında yer alan Kocaeli ili İzmit ilçesinde 1936 yılında ilk kez SEKA Kağıt fabrikasının kurulması sonucu sanayinin gelişmesiyle birlikte ticaret, bankacılık, ulaşım, eğitim, alışveriş ve diğer sektörlerde gelişim olmuştur. Yaşanan tüm gelişmeler kentin büyümesine ve gelişmesine neden olurken bir yandan da çeşitli çevre sorunları baş göstermiştir. Günümüzde İzmit Türkiye'nin en önemli sanayi kenti olma özelliğinin yanı sıra çevre sorunlarının yoğun şekilde görüldüğü bir şehirdir. Bu çevre sorunlarından birisi de hiç kuşkusuz katı atık sorunudur.

Bu çalışmanın amacı bir sanayi şehri olan Kocaeli ili İzmit ilçesinde sanayi ile birlikte gelişen barınma sorununun çözümü için oluşturulan yeni yerleşim alanlarında çevre sorunları arasında yer alan katı atık sorununun kentin gelişimi üzerindeki etkilerine dikkati çekmektir. Bu amaçla çalışma kapsamında çalışma alanı olarak İzmit ilçesinin doğusunda yer alan özellikle 1999 Marmara Depremi sonrasında yeni bir yerleşim alanı olarak gelişim gösteren Yahyakaptan Mahallesi seçilmiştir. İzmit ilçesi Yahyakaptan Mahallesi'nde nüfus artışı ve yeni yerleşim alanlarının oluşum nedenleri ortaya konulmuş, konut tipolojileri ile konut kullanım ihtiyacı kıyaslanarak, yeni yerleşim alanının mahalle üzerindeki çevresel etkilerine dair bulgular tespit edilmiş ve bölgede artan yapılaşma ve nüfusa göre katı atık miktarı çevre mühendisliği açısından TÜİK verileri yıllık atık miktarı hesaplama yöntemlerine göre incelenerek evsel atık sorununa çözümler önerilmiştir.

\section{1. İzmit İlçesi Coğrafi Konumu}

12 ilçeden oluşan Kocaeli ilinin merkez ilçesi olan İzmit Şekil 1'de görüldüğü üzere kendi adını taşıyan İzmit Körfezi'nin doğu kıyısında, Marmara Bölgesi'nin Çatalca-Kocaeli bölümünde yer almaktadır. Kuzeyinde Kandıra, doğusunda Adapazarı, güneyinde Kartepe ile Başiskele, güneybatısında İzmit Körfezi ve batı yönünde Derince yer almaktadır. Kara, demir, deniz ve hava yolları ile Türkiye'nin en önemli geçiş noktalarından biri olup; deniz ticareti açısından ülkenin en yoğun merkezlerindendir. D-100 ve E-5 TEM otoyolundan oluşan karayolu ile İstanbul'a uzaklığı 85 km'dir (URL-1 2015). Ayrıca Uluslararası Sabiha Gökçen Havalimanı'na 50 km. mesafededir. Sınırları içerisinde hava alanı da bulunan şehirde, Türkiye saati (UTC+2) için esas kabul edilen $30^{\circ}$ doğu boylamı İzmit'in doğusundan geçer. Jeolojik ve coğrafi yapı açısından $40^{\circ}-41^{\circ}$ kuzey paralelleri ile $29-31^{\circ}$ doğu meridyenleri arasında bulunmaktadır. İzmit'in yüzölçümü; belediye sınırı olarak $18,71 \mathrm{~km}^{2}$, mücavir alan olarak $39,33 \mathrm{~km}^{2}$ olmak üzere toplam $58,04 \mathrm{~km}^{2}$ dir (URL-2 2016). Aynı zamanda Kocaeli ilinin tarihi merkezi de olan İzmit, 22.03.2008 tarih ve 5747 Sayılı Kanunu ile tüzel kişilikleri kaldırılan Kuruçeşme, Bekirpaşa, Alikahya ve Akmeşe ilk kademe belediyelerinin Saraybahçe ilk kademe belediyesine katılması ve bu belediyenin adının İzmit olarak değiştirilmesiyle kurulup Kocaeli Büyükşsehir Belediyesi'nin idaresi altına alınmıştır (URL-3 2015).

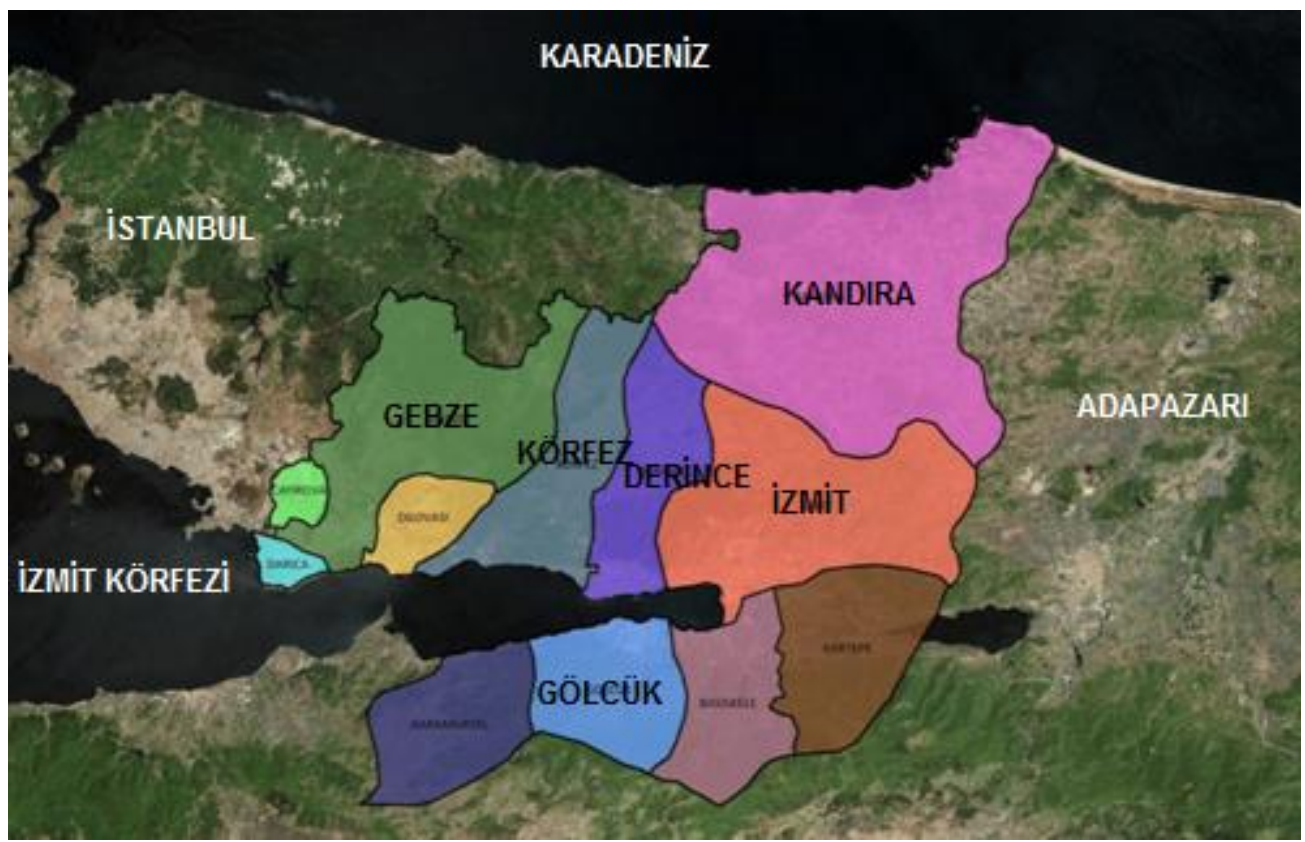

Şekil 1: Kocaeli ilçeleri ve İzmit ilçe sınırları (URL-4 2016) 


\section{2. İzmit İlçesinde Ekonomi}

İzmit ilçesi imalat sanayisi bakımından Türkiye ekonomisinde birinci sırada yer almaktadır. İzmit ekonomisinin tamamına yakını sanayiye dayalı olup; sanayinin gelişmesinde iklim şartları, ulaşım, hammadde kaynaklarına yakınlık ve enerji temininin kolay olması etkili olmuştur. Birçok büyük firmanın fabrikaları, bu şehirde bulunmaktadır. İstanbul gibi büyük bir ticaret merkezine yakın bir konumda olup, transit karayolu taşımacılığına imkân vermektedir. 5 devlet limanı, 43 özel iskele ile deniz yolu taşımacılığında da önemli bir yere sahiptir. Petrol Ofisi, Tüpraş ve Petkim 'in sırasıyla 1941, 1960 ve 1965 yıllarında kurulmasıyla petrol ürünleri sanayisi gelişmiş; son yıllarda da üretim organik kimya, metal, gıda, ilaç, gübre, boya ve tersane endüstrilerine yönelerek çok çeşitlilik kazanmıştır. Kentte sanayi etkinlikleri her zaman ülke ortalamasını aşmıştır. İlçe sınırlarında 4 adet büyük ölçekli fabrika ve 5 adet toplu sanayi sitesinde toplam 1465 işyeri bulunmaktadır. İlçede aynı zamanda ekonomiyi destekleyen 23 adet banka, işyeri açma ve çalışma ruhsatına tabi 1644 adet işyeri, işyeri kurma izni ve işletme belgesine tabi 2500 adet dükkân ve iş yeri bulunmaktadır (URL-5 2015).

\section{3. İzmit İlçesinde Demografik Yapı ve Nüfus}

Sanayinin gelişmesi ile birlikte yoğun iş göçü yaşanmış ve ilçenin nüfusu artmıştır. Kocaeli ilinin nüfusu Tablo 1'de görüldüğü gibi 2014 y1lı verilerine göre 1.722 .795 iken, İzmit merkez ilçesinin nüfusu ise 2012 yılı verilerine göre 324.535, 2014 y1lı verilerine göre 338.710'dir (URL-6 2015).

Tablo 1: Yıllara göre İzmit'in nüfusu (URL-6 2015)

\begin{tabular}{|l|c|c|c|}
\hline Yıl & Erkek Nüfusu & Kadın Nüfusu & Toplam Nüfus \\
\hline 2014 & 168.117 & 170.593 & 338.710 \\
\hline 2013 & 165.791 & 166.963 & 332.754 \\
\hline 2012 & 163.556 & 163.879 & 327.435 \\
\hline 2011 & 161.918 & 160.670 & 322.588 \\
\hline 2010 & 157.420 & 158.314 & 315.734 \\
\hline 2009 & 159.070 & 154.894 & 313.964 \\
\hline 2008 & 154.490 & 152.025 & 306.515 \\
\hline
\end{tabular}

İzmit'in gelişen ekonomiye göre nüfusunun hızla artmakta olduğu nüfus verilerinde açıkça görülmektedir. 2008 y1lında 306.515 olan ilçenin nüfusu 2014 yılında 338.710 olmuştur. Buna göre; Şekil 2'de görüldüğü üzere nüfus artış hızı ise 2009 yılında \% 2.43, 2010 yılında \%0,56, 2012 yılında \% 1,50 ve 2014 yılında \% 1,79'dur. Görüldüğü üzere nüfusta en fazla artış 2009 yılında gerçekleşmiştir. Adrese Dayalı Nüfus Kayıt Sistemi 2013 Yılı Sonuçlarına göre ilçe nüfusunun 175.137'si Kocaeli ili nüfusuna kayıtlı iken; 17868'i Sakarya, 8695'i Trabzon, 6054'ü Bolu, 4665'i Erzurum, 4381'i Artvin, 3315'i Bursa, 2214’ü Ankara, 2033’ü Ağrı ili nüfusuna kayıtlıdır. Bu durum da şehrin göç oranı ve göç alınan bölgeler hakkında bize bilgi vermektedir. Şehir ayrıca İstanbul, Bursa ve Sakarya’ya yakınlığı nedeniyle günlük göç de alınmaktadır. Hanehalkı büyüklüğü 2013 yılı verilerine göre Kocaeli ili için 3,61 iken; İzmit ilçesinde 3,31'dir (TUIKK 2013; Y1ldız ve Döker 2016).

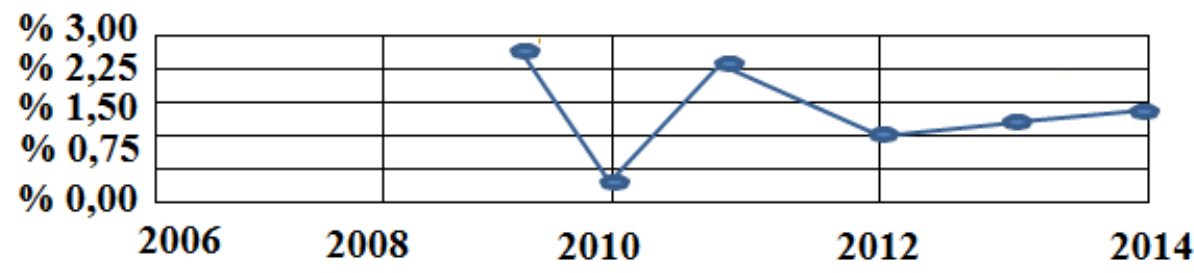

Şekil 2: Izmit'te nüfus artış hızı (URL-6 2015)

\section{4. İzmit İlçesinde Konut ve Yerleşim Özellikleri}

İzmit'in sanayi, ticaret ve nüfus açısından gelişmesi özellikle Cumhuriyet'in ilanından sonraki dönemde ivme kazanmıştır. 1930 yılında İzmit için ilk imar planı yapılmış; 1945 yılında ise mimar Jansen tarafından ikinci imar planı, 1948 yılında mimar Kemal Ahmet Aru ve Gündüz Özdeş tarafından üçüncü imar planları yapılmıştır (URL-7 2016). İzmit'in coğrafi durumu ve içinden geçen kara ve demiryollarının konumu nedeniyle şehir çizgisel doğrultuda gelişim göstermiş ve Şekil 3'de görüldüğü üzere yerleşim alanları da kara ve demiryoluna paralel doğrultuda oluşmuştur. Kemal Ahmet Aru tarafından 1959 yılında yeniden ele alınan imar planında karayolu şehrin içinden geçirilmiş, deniz doldurularak kentin çizgisel doğrultuda gelişmesi gerçekleşmiştir (URL-7 2016). 

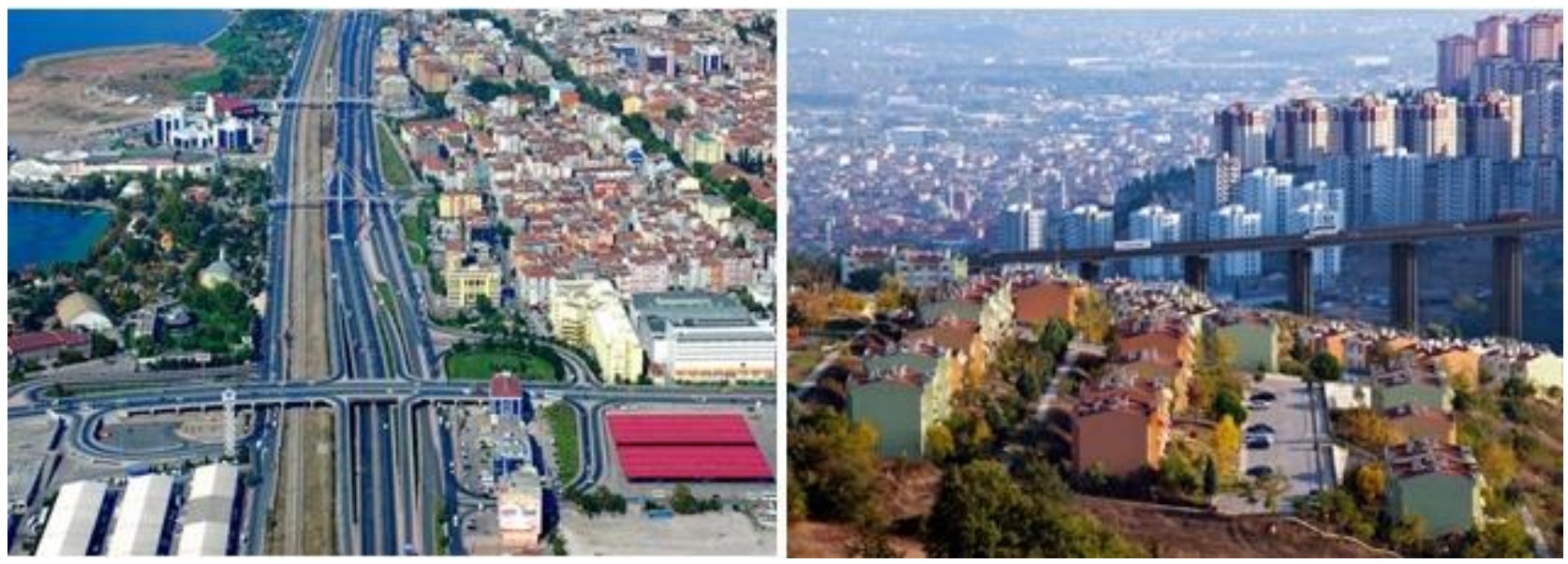

Şekil 3: Izmit'te yerleşim ve konut görselleri (URL-8 2015; URL-9 2016)

1950’li yıllardan bu yana nüfusu hızla artan şehrin en büyük sorunlarından biri konut sorunudur. Lojman, kooperatif yapıları, devlet ve özel sektör aracılığı ile yapılan toplu konut yerleşimleriyle İzmit şehrinin nüfus artışına dayalı konut sorunu çözülmeye çalışılmıştır (Demirarslan 1997). Ancak 1999 Marmara Depremi ile konut sorunu farklı bir boyut almıştır. 1999 depremi sonrasında başlatılan çalışmalar ile İzmit ilçesinde yeni yerleşim alanları belirlenmiştir. Bu yerleşim alanlarının gelişimi 2000'li yıllardan itibaren hız kazanmıştır. Son yıllarda kentsel dönüşüm uygulamaları da yeni yerleşim alanlarının gelişimini tetikleyici bir unsur olmuştur. Şekil 3'de de görüldüğü gibi özellikle İzmit'in kuzeyi, doğusu ve kuzey doğusunda yer alan alanların yerleşim alanı olarak imara açıldığı görülmektedir. Yeni yerleşim alanlarındaki konut tipolojisi ise az katlı ya da yüksek katlı apartman blokları ve müstakil evler şeklindedir. Bu yeni yerleşim alanlarından biri de Yahyakaptan Mahallesi ve yakın çevresinde gelişim göstermiştir.

\section{2. İzmit İlçesi Yahyakaptan Mahallesi’nde Yeni Yerleşim Alanlarının Gelişimi}

Kocaeli ili İzmit merkez ilçesi toplam 102 mahalleden oluşmaktadır. Bu mahallelerden biri de Şekil 4'de görüldüğü üzere İzmit' in doğusunda yer alan Yahyakaptan Mahallesi'dir. İzmit' in ilk toplu konut alanı olan mahalle esasen 1985 yılı sonrası ilk "toplu konut" uygulaması olan Emlak Bankası ve Toplu Konut İdaresi ortaklığı ile inşa edilen bir yerleşim alanı olup; 5368 birim konuttan oluşmaktadır. Toplu konut alanının 1987- 1988 döneminde inşasına başlanmış ve 1995 yılında tamamlanmıştır. Türkiye'nin ilk ve önemli toplu konut uygulamalarından biridir ve her türlü alt ve üst yapı gereksinimleri düşünülerek planlanmıştır. Bu konutlar 2 ve 3 odalı farklı plan tipinde apartman tipi yatay ve düşey bloklar şeklinde bataklık bir alanın ıslah edilmesi suretiyle inşa edilmiştir (Demirarslan 1997). 1999 Depremi sonrasında Yahyakaptan toplu konut yerleşiminin yakın çevresi öncelikle çadır kentler daha sonra ise geçici depremprefabrik konutlarına ev sahipliği yapmıştır (Demirarslan 2005). Bu süreçte Yahyakaptan toplu konut yerleşiminin alt ve üst yapı donanımlarından faydalanılmıştır.

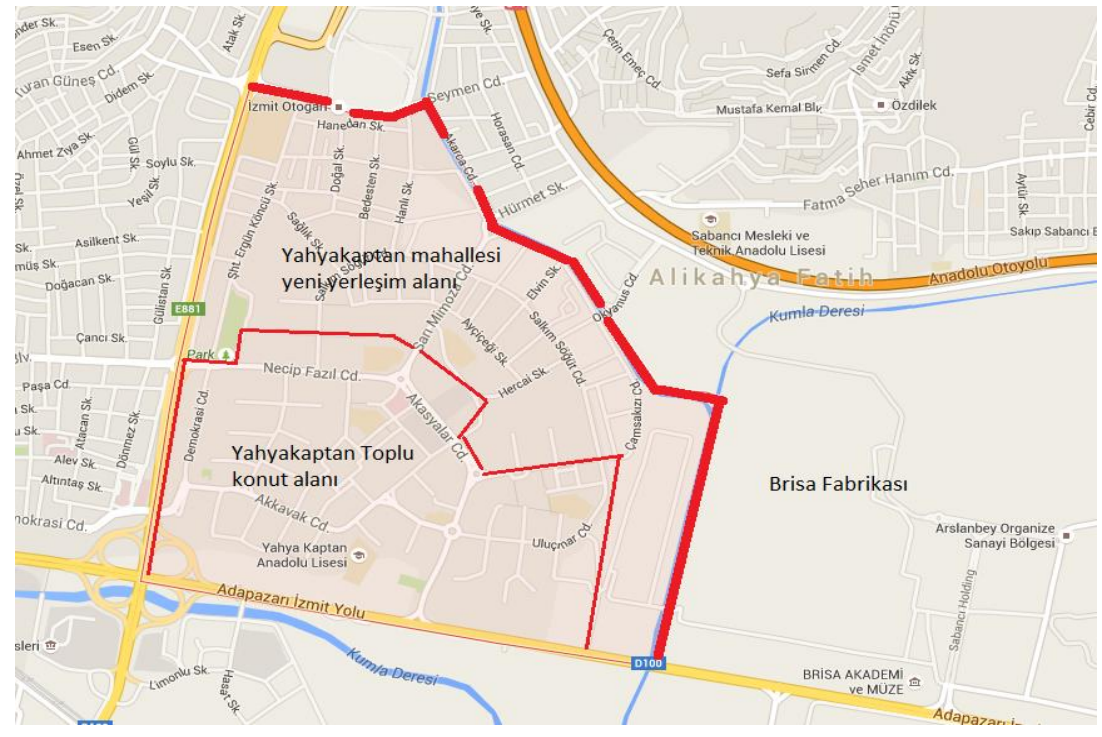

Şekil 4: Yahyakaptan Mahallesi toplu konut alanı ve yeni yerleşim alanı ile yakın çevresi gösteren haritası 
İzmit'in doğusunda yer alan ve günümüzde en kalabalık mahallerinden birisi olan, 2014 yılı verilerine göre 20.584 nüfusa sahip (URL-6 2015) Yahyakaptan Mahallesi’nin yakın çevresi, deprem sonrası geçici konut yerleşimleriyle yeni bir çehreye bürünmüş, sonrasında ise 2000'li yıllardan itibaren imara açılarak az katlı apartman blokları ve müstakil evlerden oluşan yeni yerleşim alanları kurulmuştur. Şekil 5'de de görüldüğü üzere İzmit şehir halkının depremden sonraki konut talebi az katlı bloklar ya da tek katlı müstakil evler şeklinde olmuştur. Deprem öncesi İzmit Yahyakaptan Mahallesi'nde yapılmış olan bir örneklem çalışmasında da hane halkı talebinin az katlı bloklar ya da müstakil evler şeklinde olduğu tespit edilmiştir (Demirarslan 1997). Dolayısıyla konut tipolojisinin gelişimi İzmit hane halkı için uygundur. Günümüzde toplu konut yerleşim alanının etrafında yap-satçı sektör tarafından inşa edilen yeni yerleşim alanları hızla gelişimine devam etmektedir. 2015 yılı itibariyle mahallede resmi olarak kayıtlı 1502 kapı, 757 yapı, 73 yol ve 363 parsel yer almaktadır (URL-10 2015). Yeni yerleşim alanlarının inşası ile Yahyakaptan Mahallesi'nin hem yüzölçümü hem de nüfusu artmış ve çeşitli sorunlar ortaya çıkmıştır. Bu sorunlardan biri de katı atık sorunudur.

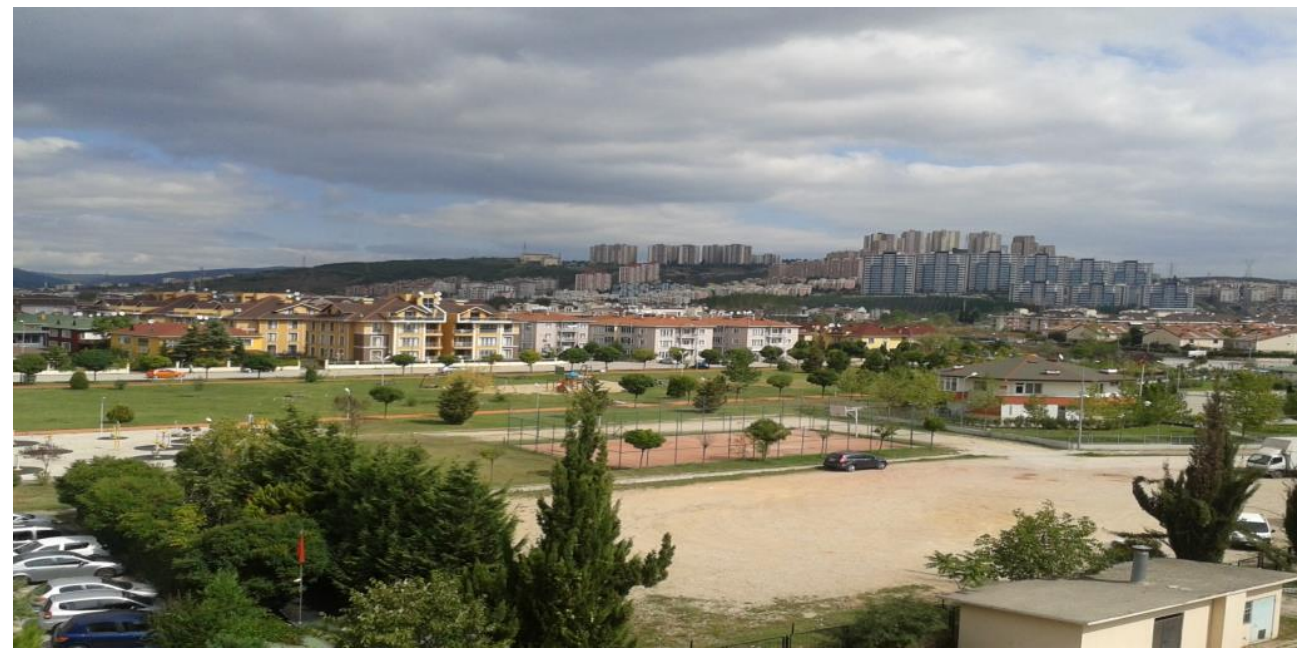

Şekil 5: Izmit Yahyakaptan Mahallesi yerleşiminden genel görünüm

\section{3. İzmit İlçesinde Katı Atık Sorunu}

Katı atıklar, evsel, ticari veya endüstriyel alanlardan oluşan; madencilik, tarımsal işlemler ve su arıtım ünitelerinin de dâhil olduğu proseslerden kaynaklanan yarı-katı çamurları da içeren, hem ayrışabilen hem de ayrışma özelliği olmayan maddeler olarak tanımlanmaktadır (Güler ve Çobanoğlu 1994). Çöp olarak da bilinen evsel katık ise hem ayrışabilen hem de ayrışma özelliği bulunmayan evsel kökenli maddelerdir. Katı atıkların toplanması ve bertaraf edilmesi, çevre kirliliğinin önlenmesi, mikrop, kemirici ve haşarat üremesinin engellenebilmesi için zorunludur. Katı atıkların çevreye etkileri biyolojik, kimyasal ve fiziksel nitelikte olabilmektedir. Doğrudan veya vektörlerle bulaşabilen cüzam, veba, kolera, dizanteri, tüberküloz, kuduz, sttma gibi hastalıklar biyolojik olumsuzluklara örnek olurken; çöp depolama alanlarında oluşan sızıntı suları ve gazlar, kimyasal ve biyolojik olumsuzluklara neden olmakta; çevreye sorumsuzca bırakılan atıklar insanlara fiziksel zararlar verebilmektedir. Yetersiz temizlik ve atık yönetimi uygulamaları ile çevre ve insan sağlığı arasındaki ilişki kalkınamamış ve/veya kalkınmakta olan ülkelerde açıkça gözlemlenmektedir (Palabıyık 2001). Ortalama nüfusa sahip bir kentte günlük çöp miktarına bakıldığında kişi başına 0,7-1 kg arasında olduğu görülmektedir. Bazı ülkelerde kişi başına günlük miktar 1,1-5 kg arasında belirlenmektedir (Güler ve Çobanoğlu 1994). D.İ.E. verilerine göre ülkemizde kişi başına günde $0,6 \mathrm{~kg}$ evsel nitelikli katı atık olmak üzere ortalama $1,0 \mathrm{~kg}$ belediye atığ üretilmektedir. Buna göre günde ortalama 68.000 ton, y1lda toplam 28,4 milyon ton civarında evsel nitelikli belediye atığı üretildiği tahmin edilmektedir. Evsel nitelikli katı atıkların kompozisyonu ile ilgili ulusal düzeyde yapılmış olan tek çalışma Devlet İstatistik Enstitüsü tarafindan 1992 yılında gerçekleştirilmiştir. Bu çalışmaya göre Türkiye'de atık kompozisyonu Tablo 2'deki gibidir: 
Tablo 2: Türkiye'de atık kompozisyonu (URL-11 2015)

\begin{tabular}{|c|c|}
\hline ATIK CINSSI & $\%$ \\
\hline Organik atık & 65,45 \\
\hline Kül-Curuf & 22,48 \\
\hline Geri kazanılabilir atık & 12,05 \\
\hline Kağıt-karton & 45,48 \\
\hline Metal & 8,62 \\
\hline Cam & 18,46 \\
\hline Plastik & 13,19 \\
\hline PET, PVC & 6,15 \\
\hline Lastik Kauçuk & 3,30 \\
\hline Tekstil & 4,80 \\
\hline
\end{tabular}

$\mathrm{Bu}$ verilere göre; evsel katı atıklar içindeki geri kazanılabilir atıklar tam bir ayrıştırmaya tabi tutulsa, depolanacak atık hacminde yaklaşı \%35 oranında bir azalma gerçekleştirilebilir. Ağılık olarak ise evsel atıkların \%12'si geri kazanılabilir atıklardır. Bu da yıllık olarak yaklaşık 3 milyon tona karşılık gelmektedir. Kentsel çevre yönetiminin önemli bir parçası olan katı atık yönetim hizmetlerine özellikle kalkınamamış ve/veya kalkınmakta olan ülkelerde yerel yönetim bütçelerinin \%10-40'ının ayrılmasına rağmen hizmetler istenen düzeyde sunulamamakta (Bartone 1997); kalkınmakta olan ülkelerdeki büyük kentsel alan nüfusunun ancak yarısına katı atık yönetimi hizmetleri sunulabilmektedir (Bartone 1991). Katı atıkların çevre ve insan sağlığına olumsuz etkileri ile birlikte yönetim sorunu olarak ele alınması; atıkların toplanması, taşınması ve uzaklaştırılması hizmetlerinin yaşanan hızlı kentleşme ve endüstrileşme ile birlikte geliştirilmesine; sorumlu aktör, kurum ve kuruluşların bilinçlendirilerek güçlendirilmesine; yeni yönetsel yaklaşım ve modellerin uygulanmasına bağlıdır. Katı atık hizmetlerinin görülmesini hedefleyen yönetsel yapılanmalarda temel amaç, toplum tarafindan üretilen atıkların en uygun ve ekonomik şartlarda çevresel, teknik ve sosyal anlamda etkin ve verimli biçimde toplanması ve uzaklaştırılmasıdır (Altunbaş 2004).

Kocaeli ilinde hızla artan sanayi faaliyetleri beraberinde titizlikle yönetilmesi gereken atık sorununu getirmiştir. Kocaeli Büyükşehir Belediyesi tarafından atık yönetimi alanında yürütülen çalışmalar, Büyükşehir Belediyesi Kanununda belirlenen görev, yetki ve sorumluluklar doğrultusunda ve mer-i mevzuat çerçevesinde yürütülmektedir. Atık yönetimi konusunda Çevre ve Şehircilik İl Müdürlüğü ve Büyükşehir Belediyesi 2006 yılında revize edilen 2872 Sayılı Çevre Kanunu ve ilgili mevzuat çerçevesinde koordineli olarak çalışmaktadırlar (URL-12 2016).

İl genelinde oluşan evsel katı atıklar, vatandaşlar tarafından kaldırım kenarında veya bina önünde bulunan konteynerlerde biriktirilmekte ya da poşetler içerisinde kaldırım kenarına bırakılmaktadır. Konteyner ve poşet kullanım oranları bölgenin durumu ve bölge halkının talebine göre değişkenlik göstermektedir. Konteynerin konulamadığı ya da toplama araçlarının konteynerlere ulaşamadığı noktalarda poşet tercih edilebilmektedir. Ancak, geçmişten bu yana süregelen sistem anlayışı, vatandaşlar tarafından kullanım kolaylığı, sokak hayvanlarının atıkları dağıtmaması, temizlik koşulları, sağlık açısından uygunluk ve geri dönüşüme katkı sağlaması gibi nedenlerle ağırlıklı olarak konteyner ile toplama metodu benimsenmektedir. Konteyner tipleri; ilçelere göre değişiklik göstermekle birlikte genellikle metal galvanizli ve plastik konteynerler tercih edilmekte olup, bazı ilçelerde pilot ölçekli olarak yer altı konteynerleri de kullanılmaya başlanmıştır. Nüfusa bağlı olarak, ilçe belediyeleri sınırlarındaki evsel katı atık miktarı farklılık göstermektedir. Bu yüzden her bölgede farklı hacimlerde konteynerler kullanılabilmektedir. Nüfus yoğunluğunun fazla olduğu bölgelerde 400 lt., 880 lt. ve 1100 lt.'lik konteyner kullanımı yaygındır (URL-12 2016).

Kocaeli ilinde 2010 yılında 496,2 bin ton evsel katı atık oluşmuş olup; bu miktar 2011 yılında \% 4,11 artışla 517 bin ton ve 2012 y1lında ise (2010 yılına göre) \% 9,85 artış oranı ile 547,5 bin tona ulaşmıştır. Kocaeli, 2012 yılında, 1,63 milyon nüfusu ile ülke geneli nüfusunun \% 2,16'sına sahiptir. Aynı yıl ilde oluşan 547,54 bin ton evsel atık, ülke geneli oluşan evsel atığın \% 2,17'sine tekabül etmektedir (URL-12 2016). 2012 yılı verilerine göre Tablo 3'de görüldüğü üzere İzmit'te evsel katı atık miktarı toplam 124.583 .750 kg'dır. Şekil 6'da da görülmektedir ki; kişi başına günlük 1,14 kg çöp çıkmaktadır. 2012 yılı verilerine göre Kocaeli ilinin en fazla evsel katı atık çıkaran ilçesi de İzmit’tir. 
Tablo 3: Kocaeli ili ilçeleri 2012 verilerine göre evsel katı atık miktarı (URL-12 2016).

\begin{tabular}{|l|c|c|c|}
\hline İlçe & Nüfus & Toplam $(\mathbf{k g})$ & Ortalama kg/kişi-gün \\
\hline Başiskele & 69.711 & 23.683 .040 & 0,94 \\
\hline Çayırova & 98.367 & 30.176 .750 & 0,85 \\
\hline Darıca & 157.304 & 47.838 .800 & 0,84 \\
\hline Derince & 125.485 & 38.173 .160 & 0,85 \\
\hline Dilovas1 & 42.292 & 13.209 .950 & 0,87 \\
\hline Gebze & 304.283 & 103.703 .310 & 0,95 \\
\hline Gölcük & 138.074 & 44.524 .470 & 0,9 \\
\hline İzmit & $\mathbf{3 0 2 . 9 6 0}$ & $\mathbf{1 2 4 . 5 8 3 . 7 5 0}$ & $\mathbf{1 , 1 4}$ \\
\hline Kandıra & 50.042 & 9.461 .690 & 0,53 \\
\hline Karamürsel & 47.433 & 14.900 .070 & 0,87 \\
\hline Kartepe & 91.375 & 37.693 .090 & 1,15 \\
\hline Körfez & 135.379 & 38.316 .390 & 0,79 \\
\hline Kocaeli & $\mathbf{1 . 6 3 4 . 6 9 1}$ & $\mathbf{2 5 . 5 4 3 . 5 2 0}$ & $\mathbf{1 , 1 4}$ \\
\hline
\end{tabular}

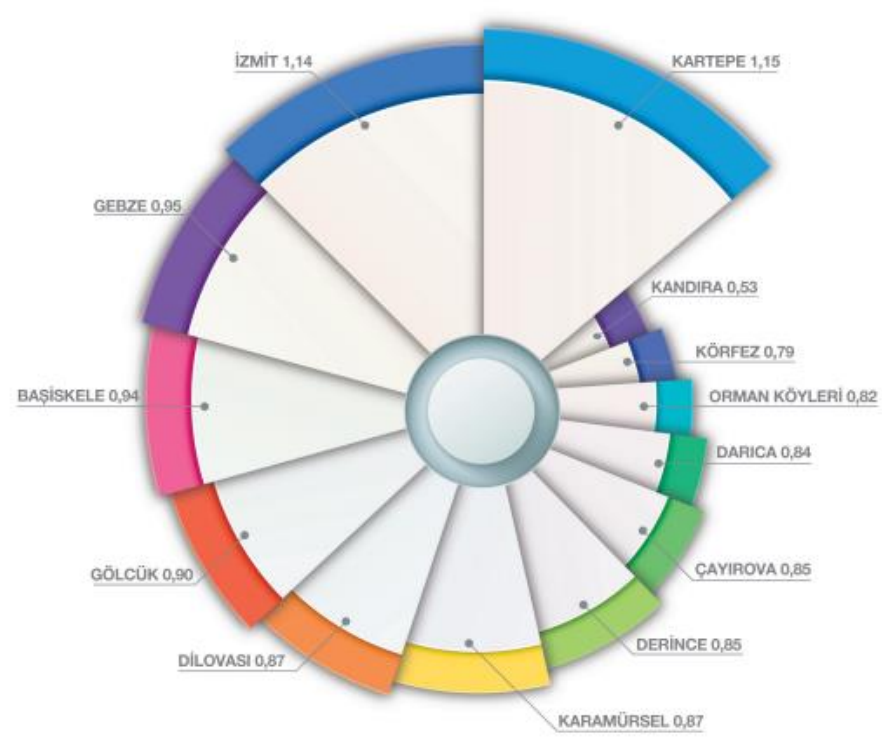

Şekil 6: Kocaeli ili ilçeleri 2012 verilerine göre evsel katı atık miktarı (URL-12 2016).

Belirtilen ilçe bazlı ortalama günlük kişi başı evsel katı atık miktarları incelendiğinde; ilçelerin gelişmişlik düzeyleri ve demografik yapıları ile ilişki kurulabilir. İzmit ilçesinin günlük hareketli nüfusu ve toplam nüfusu ile kişi başı günlük ortalama evsel katı atık miktarı 1,14 kg ile Türkiye ortalamasına eşittir (URL-12 2016). Mülga Çevre ve Orman Bakanlı̆̆ı'nın 2007/10 sayılı Genelgesi kapsamında öngörülen analiz metodu çerçevesinde; Kocaeli Büyükşehir Belediyesi sınırlarında bulunan 12 ilçe belediyesinin evsel katı atık numuneleri ile kış ve yaz dönemlerinde "Katı Atık Bertaraf Tesisleri” ve/veya "Katı Atık Aktarma İstasyonları"nda seçilen özel alanlarda Katı Atık Karakterizasyonu çalışmaları 2008 yılından itibaren düzenli olarak yapılmaktadır (URL-12 2016). Evsel katı atıkların içeriklerinin belirlenmesinde kullanılan en yaygın yöntem "Katı Atık Karakterizasyonu" ile maddesel grup analizleridir. Katı atık karakterizasyonu ile katı atıkların içerik ve miktarlarına göre uygun bertaraf yönteminin tayin edilmesi, oluşturulacak toplama, ayıklama sisteminin kurulması, düzenli depolama sahalarının ömrünün uzatılması ve iyileştirilmesi çalışmalarına kaynak oluşturulmaktadır. Katı atık karakterizasyonu, karakterizasyonun yapılacağı yerin düşük, orta, yüksek gelir seviyeleri ve çarşı olarak dört sosyo-ekonomik gruba ayrılması ve bu bölgelerden alınan atık numunelerinin gruplandırılması esasına dayanmaktadır (Yenice vd. 2009).

Tablo 4'te Kocaeli ilinde katı atık bileşenleri yıllara göre sınıflandırılarak verilmiştir. Katı atık karakterizasyonu sonuçları değerlendirildiğinde; yaklaşık \% 46,2'sını organik atıklar, \% 23,7'sini ambalaj atıkları geri kalan \% 30,01'ini diğer atık grupları oluşturmakta olup; son üç yıl seyrinde bu kategorizasyon ayrımlarında çok fazla farklılık gözlemlenmemektedir. 
Tablo 4: Evsel katı atık kategorizasyonu (URL-12 2016).

\begin{tabular}{|c|c|c|c|}
\hline Katı Atık Bilessenleri \% & $\mathbf{2 0 1 0}$ & $\mathbf{2 0 1 1}$ & $\mathbf{2 0 1 2}$ \\
\hline Organik Atıklar & 45,90 & 46,28 & 46,35 \\
\hline Ambalaj Atıkları & 22,38 & 23,71 & 24,74 \\
\hline Diğerleri & 31,72 & 30,01 & 28,91 \\
\hline Toplam & 100 & 100 & 100 \\
\hline
\end{tabular}

İlçe belediyelerince toplanan evsel katı atıklar; Büyükşehir Belediyesi iştiraki olan ve 1996 yılında kurulan "İzmit Atık ve Artıkları Arıtma, Yakma ve Değerlendirme Anonim Şirketi” kısa adı ile IZAYDAŞ tarafindan işletilen Solaklar Köyü Mevkii (İzmit) ve Çiçektepe Mevkii’nde (Dilovası) bulunan “Katı Atık Bertaraf Tesisleri”nde, “Atıkların Düzenli Depolanmasına Dair Yönetmelik"in teknik esasları doğrultusunda bertaraf edilmektedir. Bertaraf tesislerine belediyeler harici atıklar da gelmektedir. 2015 yılı verilerine göre; İzmit Belediyesi tarafından İzmit ilçesinde günde ortalama 350 ton çöp toplandığı belirtilmektedir. Bu çöplerin toplanmasında ise 200 personelin görev aldığı, bazı mahallelerde her gün çöp toplanmaktayken bazı mahallelerde haftanın 3-4 günü çöp toplandığı Belediye tarafından bildirilmektedir. İzmit'in mahallelerinde de 6000'den fazla çöp konteyneri yer almaktadır (URL-13 2015). Tablo 5'de görülmektedir ki; Kocaeli ilinde İzmit ilçesinin katı atık yönetimi hizmetleri için 2012 yılında 15.716.920 TL harcanmıştır. 2014 yılında ise katı atıkların toplanması için 83 milyon 113 bin liralık iş ihalesi gerçekleştirilmiştir (URL-14 2016). Kocaeli genelinde katı atık için en fazla harcamanın yapıldığı ilçenin İzmit olduğu Tablo 5'de görülmektedir. Nüfusun kalabalık, ekonomik ve sosyo-kültürel düzeyin yüksek olduğu Yahyakaptan Mahallesi ve yakın çevresinde de aynı şekilde çöp konteynerleri ile evsel katı atıklar toplanmaktadır.

Tablo 5: İlçelere göre Kocaeli'nde belediyelerin çevresel harcamaları, 2012 (URL-15 2015).

\begin{tabular}{|c|c|c|c|c|c|}
\hline & $\begin{array}{l}\text { Toplam Çevresel } \\
\text { Harcamalar }\end{array}$ & $\begin{array}{l}\text { Su Hizmetleri } \\
\text { Harcamaları }\end{array}$ & $\begin{array}{l}\text { Atıksu Yönetimi } \\
\text { Hizmetleri } \\
\text { Harcamaları }\end{array}$ & $\begin{array}{l}\text { Atık Yönetimi } \\
\text { Hizmetleri } \\
\text { Harcamaları } \\
\end{array}$ & $\begin{array}{l}\text { Diğer Çevresel } \\
\text { Harcamalar* }\end{array}$ \\
\hline Türkiye & 10.236 .991 .552 & 3.532 .738 .004 & 1.473 .460 .916 & 3.700 .832 .724 & 1.529 .959 .308 \\
\hline KOCAELİ & 557.124 .953 & 375.298 .209 & 20.628 .011 & 95.385 .843 & 65.812 .890 \\
\hline Büyükșehir & 461.733 .045 & 375.298 .209 & 20.628 .011 & - & 65.806 .825 \\
\hline İzmit & 15.716 .920 & - & - & 15.716 .920 & - \\
\hline Başiskele & 10.192 .365 & - & - & 10.186 .300 & 6085 \\
\hline Çayırova & 4.375 .420 & - & - & 4.375 .420 & - \\
\hline Darıca & 6.054 .594 & - & - & 6.054 .594 & - \\
\hline Derince & 5.566 .047 & - & - & 5.566 .047 & - \\
\hline Dilovası & 5.267 .096 & - & - & 5.267 .096 & - \\
\hline Gebze & 16.310 .888 & - & - & 16.310 .888 & - \\
\hline Gölcük & 12.136 .580 & - & - & 12.136 .580 & - \\
\hline Kandıra & 1.196 .674 & - & - & 1.196 .674 & - \\
\hline Karamürsel & 2.192 .199 & - & - & 2.192 .199 & - \\
\hline Kartepe & 5.034 .170 & - & - & 5.034 .170 & - \\
\hline Körfez & 10.628 .955 & - & - & 10.628 .955 & - \\
\hline
\end{tabular}

\subsection{Yahyakaptan Mahallesi ve yakın çevresinde gelişen yerleşim alanlarında çevre ve katı atık sorunu}

Yukarıda da belirtildiği üzere Kocaeli ilinin nüfusu en yoğun, en fazla göç alan, sosyo-kültürel ve ekonomik düzeyi yüksek ilçelerinden biri olan İzmit'te 2014 yılı verilerine göre 22.324 nüfuslu Yenişehir Mahallesi'nden sonra İzmit'in en kalabalık ikinci mahallesi olan Yahyakaptan Mahallesi'nin toplu konut alanı olarak inşa edilen bölümü bir toplu konut yerleşim alanı olarak planlandığından kanalizasyon, elektrik, haberleşme-iletişim, aydınlatma, araç yolu, yaya ve bisiklet yolları, yeşil alan ve rekreasyon alanları, otopark, katı atık vb. alt ve üst yapı olanakları açısından barındırdığı nüfusun gereksinimlerini karşılayacak düzeyde iken; son yıllarda toplu konut alanının yakın çevresinin imara açılmasıyla bölgenin nüfusu artmış; alt ve üst yapı hizmetleri yetersiz kalmıştır.

Toplu konut alanının içerisinde yapılan ring yolu yeni yerleşim alanlarının İzmit ilçe merkezine bağlantısını sağlayan ana yol halini almış; böylelikle trafik önemli bir sorun haline dönüşmüştür. Site yerleşimleri arasındaki sokak ve yollar dar yapılmış; sitelerin otoparkları olmadığı için ya da hane halkı sayısı ile orantılı planlanmadığı için dar sokaklar otopark halini almıştır. Dolayısıyla çöp toplama araçları mahallenin çöplerini toplama esnasında park eden araçlardan ötürü trafik sıkışıklığına sebebiyet vermektedir. Sitelerin katı atık biriktirme yerleri de ekseriyetle planlı düşünülmediğinden ya da hiç düşünülmediğinden lüks konut olarak kabul gören bu konutların çevresinde evsel katı atıkların çöp yığınları oluşturduğu görülmektedir. Şekil 7'de görüldüğü gibi bu çöp yığınları sadece görüntü ve çevre 
kirliliğine sebebiyet vermekle kalmamakta zaman zaman yangın gibi felaketlere de yol açmaktadır. Oysaki İzmit Belediyesi'nden alınan bilgiye göre mahallede çöp toplama işlemi her gün sabah saatlerinde gerçekleştirilmektedir. Ancak mahallenin evsel katı atıklarının depolandığ Çöp konteynerlerinde yer alan evsel katı atıkların haricinde mobilya atıkları ve inşaat atıkları (klozet, fayans kırı ̆̆ı, beton ve tuğla parçaları, halı vb.) ile peyzaj düzenlemeleri ve bahçe bakımlarından çıkan bitkisel atıklar yoğun bir şekilde çöp konteynerlerinin etrafında toplanmaktadır. Şekil 8 ve 9'da görüldüğü gibi bu tür katı atıklar evsel katı atıkların toplanması için tahsis edilmiş özel çöp araçları ile toplanmadığından bertarafi da mümkün olamamakta ve çevre ile görüntü kirliliğine yol açmaktadır. Ayrıca özellikle mobilya atıkları tehlikeli atık kapsamına girdiği için bu tür atıklar çevre için büyük tehlike arz etmektedir. Bu tür atıkların toplanmasında çöp toplayıcılar aktif şekilde rol oynamaktadır. Mahallede evsel katı atıkların ayrışımını sağlayan özel konteynerlerin sayısının az olduğu ve bunların kullanım alışkanlığının mahalle sakinleri tarafından kazanılmamış olduğu görülmüştür. Mahallede ambalaj atıkları için konulmuş konteynerlere normal çöpler atılmaktadır. Yağ toplama, atık pil vb. konteynerlerin sayısı ise oldukça azdır.

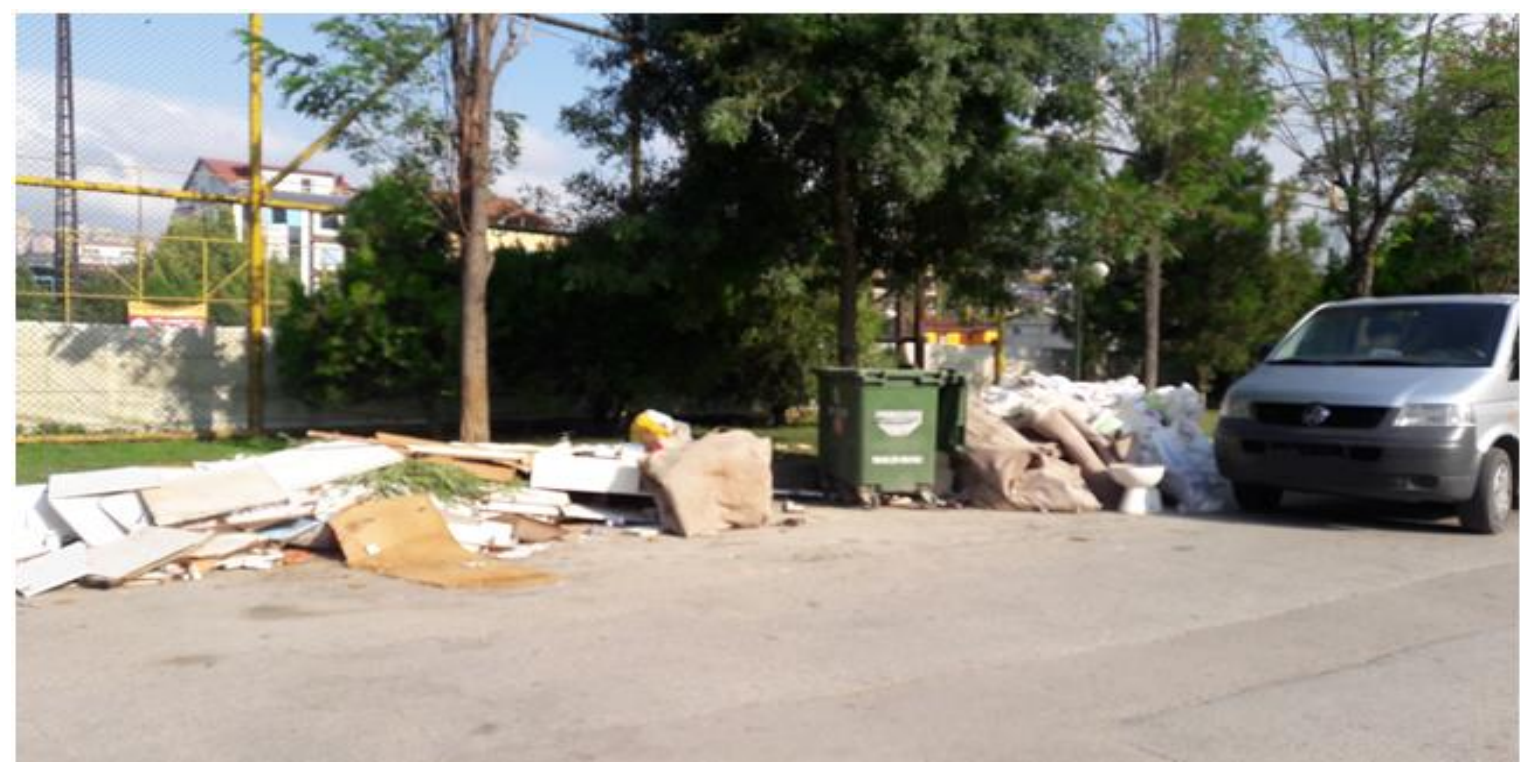

Şekil 7: Yahyakaptan Mahallesi'nde katı atık sorunu

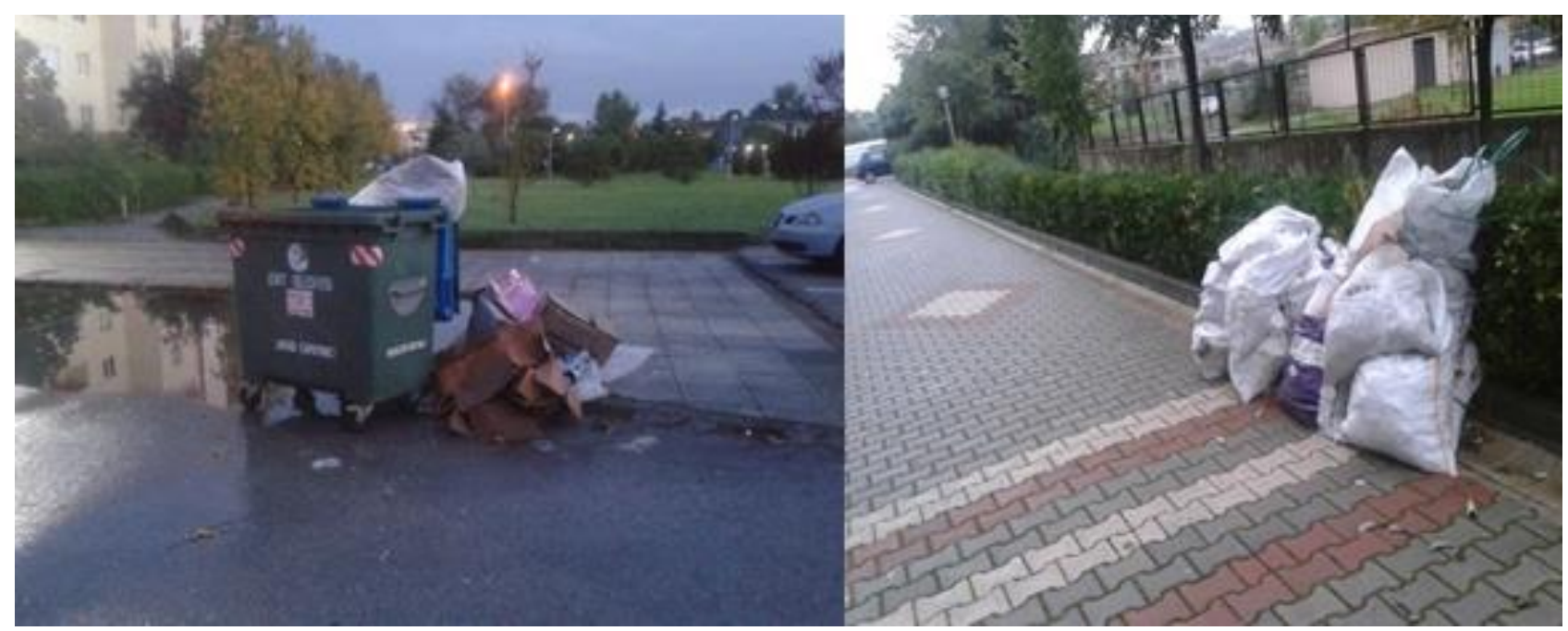

Şekil 8: Yahyakaptan Mahallesi'nde katı atık sorunu 

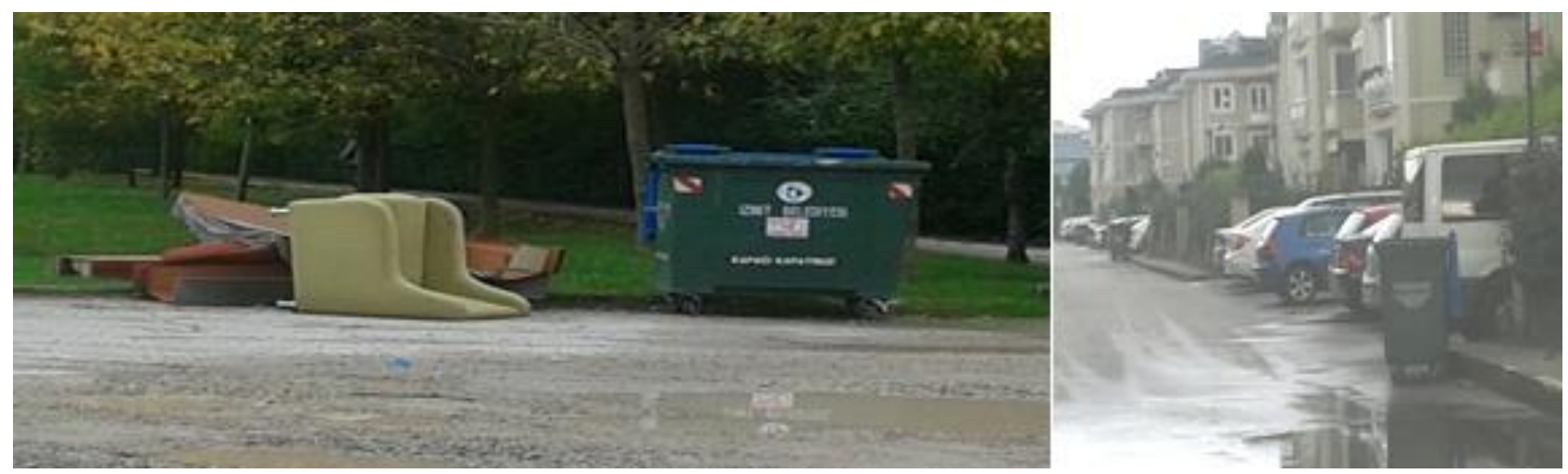

Şekil 9: Yahyakaptan Mahallesi'nde katı atık sorunu

\section{2. Çalışma alanında katı atık değerlendirmesi}

Çalışma alanının günümüzdeki katı atık durumu ile gelecekteki durumunun belirlenebilmesi için öncelikle Yahyakaptan Mahallesi'nin nüfusu Tablo 6'da tespit edilmiştir. 2.09 km²'lik yüzölçümü bulunan mahallede nüfus yoğunluğu 9848 kişi $/ \mathrm{km}^{2}$ 'dir.

Tablo 6: Çalışma Alanı İmit Yahyakaptan Mahallesi Nüfusu (TÜÍK 2013)

\begin{tabular}{|c|c|}
\hline YIL & NÜFUS \\
\hline 2014 & 20.584 \\
\hline 2013 & 19.928 \\
\hline
\end{tabular}

TÜİK 2012 verilerine göre Kocaeli ilinde atık hizmeti verilen 13 belediye ve 1.509 .224 kişiden toplanılan yıllık toplam atık miktarı 555.061 ton olarak belirlenmiştir. Bu miktar hesaba katıldığında kişi başı üretilen katı atık miktarı $1,01 \mathrm{~kg} /$ gün olduğu anlaşılmaktadır. Hesaplamalarda bu miktar kullanılırsa 2013-2014 yılları arasındaki Yahyakaptan Mahallesi'ndeki katı atık değişimi Tablo- 7' de verilmektedir.

Tablo 7: Çalışma alanının yıllara göre katı atık değişimi

\begin{tabular}{|c|c|c|}
\hline YIL & Günlük miktar (Ton) & Yıllık miktar (Ton) \\
\hline 2014 & 20.789 & 7588 \\
\hline 2013 & 20.127 & 7346 \\
\hline
\end{tabular}

Tablo 7'den de anlaşılacağı üzere Yahyakaptan Mahallesi'ndeki katı atık miktarındaki yıllık artış \%1,61 değerinde olmuştur. İller Bankası nüfus projeksiyon yöntemine göre ileriki yıllardaki nüfus tahminleri yapılırsa Tablo 8'deki nüfuslara göre Yahyakaptan Mahallesi’ndeki günlük ve yıllık katı atık miktarlarındaki değişiklik elde edilmektedir. Çalışma alanının nüfus tahmininde İller Bankası yöntemi olarak da bilinen Eksponansiyel (yarı logaritmik) Artış Yöntemi kullanılmıştır. Bu yöntemde;

$$
C=\left(\sqrt[a]{\frac{N_{y}}{N_{e}}}-1\right) \times 100
$$

Formülü kullanılmaktadır. Formülde;

Ç : Çoğalma katsayısını,

a : İki nüfus arasında geçen süre (yıl),

$\mathrm{N}_{\mathrm{y}}$ : Beldenin yeni nüfus sayım değerini,

$\mathrm{N}_{\mathrm{e}}$ : Beldenin eski nüfus sayım değerini temsil etmektedir.

İller bankası şartnamesine göre;

$$
\begin{aligned}
& C \zeta>=3 \text { ise } \quad \rightarrow C ̧=3, \\
& C \zeta<=1 \text { ise } \quad \rightarrow C ̧=1 \text { alınmaktadır }
\end{aligned}
$$


Gelecek yılların nüfus tahmini içinse aşağıdaki formül kullanılmaktadır;

$$
N_{y}=N_{e}^{*}\left(1+\frac{\bar{C}}{100}\right)^{n}
$$

$\mathrm{N}_{\mathrm{y}}$ : Beldenin yeni nüfus sayım değeri

$\mathrm{N}_{\mathrm{e}}$ : Beldenin eski nüfus sayım değeri

Ç : Çoğalma katsayısı olarak ele alınmıştır.

Tablo 8'deki bilgiler baz alınarak Yahyakaptan Mahallesi'nde tahmin edilen yıllara göre katı atıklardaki değişim miktarları hesaplandığında ise Şekil 10'daki veriler elde edilmektedir. 2015 yılında mahalle nüfusunun 21202, günlük katı atık miktarının 21,414 ton, yıllık katı atık miktarının 7816 ton olacağ 1,2025 yılında ise mahalle nüfusunun 28,49, günlük katı atık miktarının 28.777 ton, yıllık katı atık miktarının 10503 ton olacağı hesaplanmıştır. Görülmektedir ki; İzmit ilçesi Yahyakaptan Mahallesi İzmit'in sosyo-ekonomik yapısı nedeniyle nüfus artışı yaşamakta ve nüfus artışına doğru orantılı olarak katı atık üretmektedir. İlerleyen yıllarda da mahalle nüfusundaki artışla doğru orantılı olarak çıkan katı atık miktarı da artacaktır.

Tablo 8: Çalışma alanında yıllara göre nüfus projeksiyonu ve katı atık tahmini

\begin{tabular}{|c|c|c|c|}
\hline YIL & Tahmin edilen nüfus & Günlük miktar (Ton) & Yıllık miktar (Ton) \\
\hline 2015 & 21202 & 21,41 & 7816 \\
\hline 2016 & 21830 & 22,04 & 8047 \\
\hline 2017 & 22493 & 22,71 & 8292 \\
\hline 2018 & 23167 & 23,39 & 8540 \\
\hline 2019 & 23862 & 24,10 & 8796 \\
\hline 2020 & 24578 & 24,82 & 9060 \\
\hline 2021 & 25315 & 25,56 & 9332 \\
\hline 2022 & 26075 & 26,33 & 9612 \\
\hline 2023 & 26857 & 27,12 & 9900 \\
\hline 2024 & 27663 & 27,93 & 10197 \\
\hline 2025 & 28493 & 28,77 & 10503 \\
\hline
\end{tabular}

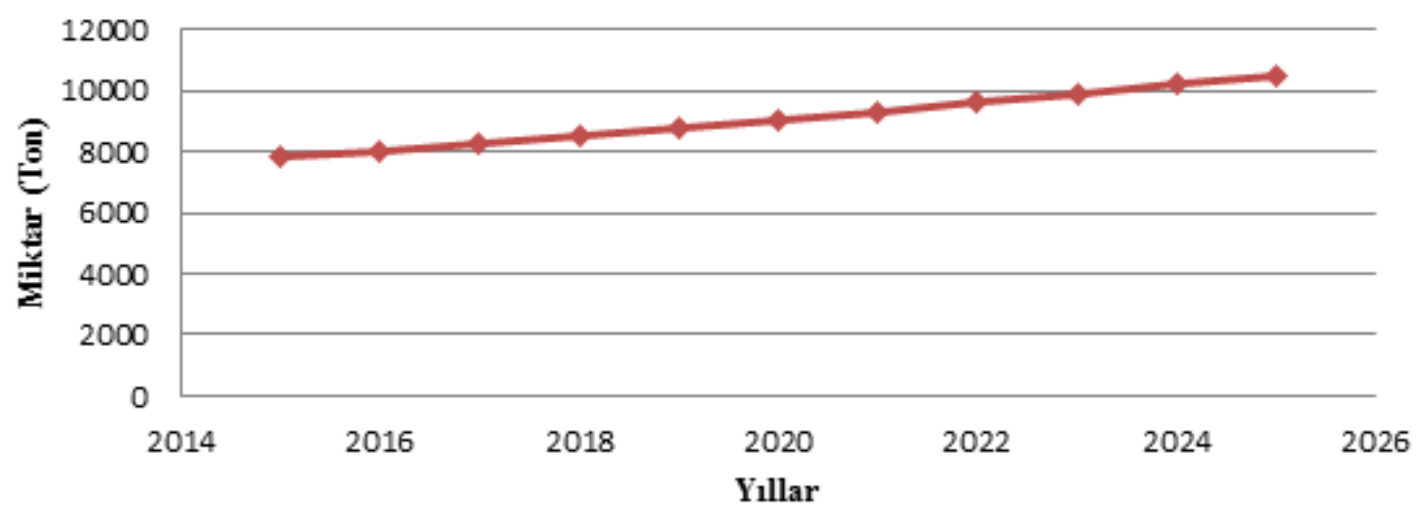

Şekil 10: Yahyakaptan Mahallesi'nde gelecek yıllara ait katı atık miktarı değişim grafiği

\section{Sonuç ve Öneriler}

Son yıllarda katı atıklardan kaynaklanan sorunlar ülkemizin en önemli çevre sorunlarındandır. Nüfus artışına paralel olarak katı atık miktarları da artmakta, özellikle büyük kentlerimizde tüketim alışkanlıklarının değişimine paralel olarak atık kompozisyonu da hızla değişmektedir. İzmit Yahyakaptan Mahallesi devamlı gelişmekte ve büyümekte olan bir sanayi şehrinin katı atık sorunu için seçilmiş önemli bir yerleşim alanıdır. Bu alanda gözlemlenen katı atık toplama, depolama, bertaraf gibi katı atık yönetimini ilgilendiren sorunlara getirilen çözüm önerileri Türkiye'nin tün yerleşim alanları için de uygulanabilir olacaktır. Yapılan inceleme ve gözlemler sonucunda getirilen çözüm önerileri aşağıdaki gibi verilebilir: 
- Öncelikle İzmit ilçesinde mahallelere göre detaylı bir katı atık envanterinin hazırlanması gerekmektedir. $\mathrm{Bu}$ envantere göre geleceğe yönelik, özellikle geri dönüşebilir maddelerin ayrı toplanabileceği bir katı atık yönetim planı mahalleler bazında hazırlanmalıdır.

- Katı atık ile ilgili yasa ve yönetmelikler kapsamında yerleşim alanlarında katı atıkların toplama koşulları yeniden düzenlenmelidir. $\mathrm{Bu}$ nedenle mahallelerde yeterli gelmeyen atık konteynırları hacimleri daha yüksek olanlar ile değiştirilebilir. Atık toplama saatleri yeniden düzenlenerek gün içerisinde konteynırlardaki atıkların yığılmaları önlenebilir. Bunun yanında mobilya, moloz gibi hacimli atıklar özel bir ekiple haneler bazında toplanmalıdır.

- Yeni ve mevcut yerleşim alanlarında binaların çöp toplama yerleri mimari ile birlikte dış çevre, bina ve çevre ilişkisi dikkate alınarak estetik bir şekilde tasarlanmalıdır.

- Mahallelerde meskenlere ve iş yerlerine ait çöp toplama yerleri nüfus- katı atık oranı ilişkisine göre tasarlanmalıdır.

- Katı atık yönetimi konusunda özel sektörün teşvik edilerek, uygun teknolojilerle yatırım yapmaları sağlanmalıdır. Bunun için fizibilite raporları hazırlanarak hangi noktalarda nasıl bir toplama sisteminin yapılacağı önceden belirlenmelidir. Yap-işlet-devret sistemiyle ayırma ve geri dönüșüm merkezleri kurulabilir.

- Geri kazanım konusunda yapılan çalışmalar süratle yaygınlaştırılmalıdır. Belediyelerin bu konuda faaliyette bulunurken karşılaş̧ıkları bürokratik engeller kaldırılmalıdır. Ayrıca bu tür uygulamalar için belediyeler ve halk özendirilmelidir. 13/07/2015 tarih ve 25874 sayılı Resmi Gazete'de yayınlanarak yürürlüğe giren 5393 sayılı Belediye Kanunu'nun 15. maddesine göre belediyeler, "katı atıkların toplanması, tașınması, ayrıștırılması, geri kazanımı, ortadan kaldırılması ve depolanması ile ilgili bütün hizmetleri yapmak ve yaptırmak" ile ilgili olarak yetki ve imtiyaza sahip kılınmışlardır. Kanun, belediyeler bu hizmetleri Danıştay'ın görüşü ve İçişleri Bakanlığı'nın kararıyla süresi 49 yılı geçmemek üzere imtiyaz yoluyla da devredebilirler (Madde:15) demektedir. Görüleceği gibi, Kanun belediyelere çöp hizmetleri konusunda sadece görev ve sorumluluk vermemiș aynı zamanda yetki ve imtiyaz vermiștir. İmtiyaz, bu hizmetleri belediyelerden başka kimsenin yapamayacağı anlamına gelmektedir. Belediyelerin imtiyazı devredebilmeleri ise belirli koşullar ile hak devri anlamına gelmekte ve imtiyazı devralanın çöp hizmeti konusunda belediyenin sahip olduğu tüm hak, ayrıcalık ve çıkara sahip olması anlamına gelmektedir. Büyükşehirlerde çöp hizmetlerinin yürütülmesi, 5216 sayılı Büyükşehir Belediye Kanunu'nda "büyükşehir, ilçe ve ilk kademe belediyelerinin görev ve sorumlulukları" başlığı altında düzenlenmiştir (Madde:7). Buna göre büyükş̧ehir belediyelerine, "büyükş̧ehir katı atık yönetim plânını yapmak, yaptırmak; katı atıkların kaynakta toplanması ve aktarma istasyonuna kadar taşınması hariç katı atıkların ve hafriyatın yeniden değerlendirilmesi, depolanması ve bertaraf edilmesine ilişkin hizmetleri yerine getirmek, bu amaçla tesisler kurmak, kurdurmak, işletmek veya işlettirmek; sanayi ve tıbbî atıklara ilişkin hizmetleri yürütmek, bunun için gerekli tesisleri kurmak, kurdurmak, işletmek veya işlettirmek” görevi verilmiștir (Madde: 7-i). Buna göre işgücü maliyetlerinin yüksek olması önemli bir sorundur. Çöp hizmetini taşeron şirketlere gördüren belediyelerin temel ve bilinen gerekçesi işgücü maliyetlerini azaltmaktır. Çöp hizmetlerini taşeronlaştırmanın bir diğer önemli gerekçesi ise belediye iş̧̧isinin verimsiz çalıștığı ve düzgün çalışmadığı iddiasıdır. Kamu hizmetlerinde çalışanların verimlilik ölçümü son yılların en çok tartışılan konularından birisidir. Bir belediye işçisinin, bir çöp iş̧̧isinin verimliliğini ölçmek tartışmaların en önemli konu başlıklarından birisidir. Ancak evsel katı atıkların toplanması, ayrıştııılması ve gerekiyorsa bertarafında özel sektörden yardım alınabilmesi mümkün olup; bu durum belediyelerin fiziki ve maddi olanakları ile belirlenebilecek bir durumdur.

- Kamuoyu katı atık ve geri kazanım konusunda bilinçlendirilmeli, özellikle ilköğretim okullarında daha etkin bir çevre ders programı yapılmalıdır. Bu kapsamda katı atık ve geri kazanım konularında uygulamalı eğitimlere ağırlık verilmelidir.

- Calıșma alanındaki katı atıkların karakterizasyonu ve geri dönüşüm oranı resmi olarak belirlenmemiştir. Bu nedenle ivedilikle bu konuyla ilgili bilimsel çalışmaların başlatılması önerilmektedir. Bu çalışmanın da yapılması gerekli olan çalışmaların başlatılmasında bir başlangıç noktası olması amaçlanmaktadır.

- Geri kazanım konusunda belediyelerin "Kocaeli Atık Geri Kazanım Projesi" kapsamında ilçe belediyeleri ile birlikte şehrin ekonomik ve sosyal kompozisyonu göz önünde bulundurularak bölgesel dağılımlar yapılmış, müteakiben Bakanlıktan Çevre İzin/lisanslı firmalar ve yetkilendirilmiş kuruluşlar da sisteme dahil edilerek; haneler, kamu kurumları, iş yerleri, okullar vb. yerlerde oluşan ambalaj atıkları, atık piller, elektronik atıklar, kızartmalık atık yağlar gibi atıkların ayrı toplanması konusunda ülke genelinde örnek olacak çalışmalar yürütülmüştür. Bu gibi örnek çalışmaların yapılmasının hızlandırılması önemlidir. Bu çalışmaların yapılmasını yavaşlatan kamu kurumları arasındaki bürokratik yazışmalar, bertaraf alanlarının ayrılması için belediye tarafından yürütülen imar ve iskân çalışmalarındaki bürokratik işleyişin yavaş seyretmesi gibi hususlar konusunda örgütleyici çalışmalar yapılmalıdır.

- Çok katlı binalarda çöp toplama bacalarının yapılması az katlı binalar ve sitelerde de çöp toplama odası/ mekânı yapma gerekliliği üzerinde çalışmalar tasarımda dikkate alınmalıdır.

- Evsel atıkların ayrıştııılması özellikle hanelerde zorunlu hale getirilmelidir. Konut ve diğer yapıların mimari planlamalarında ve inşalarında çöplerin toplanması için bacalar planlanmaktadır. Çöp ayrışmaları daha bu bacalarda bina içlerinde yapılmakta olup; Avrupa ve Amerika gibi gelişmiş ülkelerde örnekleri bulunmaktadır. Çevre ve Şehircilik Bakanlığı İmar Yönetmeliğinde bu konuda değişiklik yapmayı öngörmektedir. Bakanlık tarafından yeni yapılacak binalarda atık bacası sistemi kurulması planlanmaktadır. Bu da konuyla ilgili önemli bir gelișmedir. Gelişmiş ülkelerdeki sistemlerde binalarda bir elektronik sistem yer almaktadır. Sistem borular aracılığı ile bacaya 
bağlanmaktadır. Elektronik sistem yardımıyla geri dönüşebilen maddeler ayrıştırılmakta ve ilgili haznelere boşaltılmaktadır. Türkiye'de de yapılacak yönetmelik değişikliği ile aynı sistemin binalarda uygulanmaya başlanması planlanmaktadır (URL-16 2016; URL-17 2016).

- Çöp toplama günlerinin ve hatta saatlerinin dışında binaların önüne çöp konulmasını önleyecek yaptırımlar titizlikle uygulanmalıdır.

Sonuç olarak; Anayasamızın 56. maddesine göre herkes sağlıklı ve dengeli bir çevrede yaşama hakkına sahiptir. Çevreyi geliştirmek, çevre sağlığını korumak ve çevre kirlenmesini önlemek Devletin ve vatandaşların ödevidir. Yeni yerleşim alanlarının çevre sorunları dikkate alınarak planlanması ve bu planlamalarda bilhassa katı atık sorununun göz önünde bulundurulması temiz, yaşanabilir ve sürdürülebilir bir çevre için gereklidir.

\section{Kaynaklar}

Altunbaş H.D., (2004), Kentsel Katı Atıklar ve Yönetimi", Çevre Sorunlarına Çağdaş Yaklaşımlar: Ekolojik, Ekonomik, Politik ve Yönetsel Perspektifler, (C. Marin, U. Yıldırım, Ed. ), Beta, İstanbul, s: 103-124.

Bartone C.R., (1991), Institutional and management approaches to solid waste disposal in large metropolitan areas, Waste Management \& Research, 9(6), 525-536.

Bartone C.R., (1997), Strategies for improving urban waste management: a view from the world bank, International Conference on Development and Environmental Impact, 21-23 September, Riyadh, Saudi Arabia.

Demirarslan D., (1997), Endüstri şehirlerinde orta gelir grubundaki insanların ihtiyacı olan toplu konutların iç mekân kullanım alanları standartlarına ilişsin sistem önerilerinin geliştirilmesi ve ülkemizden İzmit örneği, Doktora Tezi, MSÜ Fen Bilimleri Enstitüsü, İstanbul.

Demirarslan D., (2005), Yaşanan depremler sonrası acil barınma ihtiyacının karşılanması, Kocaeli Deprem Sempozyumu, Kocaeli, s.340-347.

Demirarslan K.O., (2005), Kentleşme ve çevre sorunları bağlamında katı atıklar ve Kocaeli örneği, Yüksek Lisans Tezi, KOÜ Sosyal Bilimler Enstitüsü, Kocaeli.

Güler Ç., Çobanoğlu Z., (1994), Tehlikeli atıklar, TC. Sağlık Bakanlığı Çevre Sağlığı Temel Kaynak Dizisi No:30, Ankara.

Palabıyık, H., (2001), Belediyelerde Kentsel Katı Atık Yönetimi: İzmir Büyükşehir Belediyesi Örneği, Doktora Tezi, DEÜ Sosyal Bilimler Enstitüsü, İzmir.

TUIKK, 2013, Adrese Dayalı Nüfus Kayıt Sistemi Sonuçları, 2013, http://www.tuik.gov.tr/VeriTabanlari.do?ust_id=109\&vt_id=28, [Erişim 24 Temmuz 2016].

URL-1, (2015), http://www.tuik.gov.tr/ilGostergeleri/iller/KOCAELI.pdf, [Erisim 10 Eylül 2015].

URL-2, (2016), http://www.kocaeli.bel.tr/icerik/izmit/2415/19066, [Erişim 26 Temmuz 2016].

URL-3, (2015), https://www.tbmm.gov.tr/kanunlar/k5747.html, [Erişim 10 Eylül 2015].

URL-4, (2016), http://www.marka.org.tr/sayfa/1/2/kocaeli , [Erişim 26 Temmuz 2016].

URL-5, (2015), http://www.izmit.gov.tr/default_B0.aspx?content=329, [Erişim 13 Eylül 2015].

URL-6, (2015), http://www.nufusu.com/ilce/izmit_kocaeli-nufusu, [Erișim 14 Eylül 2015].

URL-7, (2016), http://www.kemalahmetaru.itu.edu.tr/aru.pdf, [Erişim 26 Temmuz 2016].

URL-8, (2015), http://www.kocaeli.bel.tr/icerik/izmit/2415/19066, [Erișim 10 Eylül 2015].

URL-9, (2016), http://kocaelikentkonseyi.org/upload/galeri/ALAEDD\%C4\%B0N-KO\%C3\%87-Modern-izmit.jpg, [Erişim 26 Temmuz 2016].

URL-10, (2015), http://keos.izmit.bel.tr/keos/, [Erișim 13 Eylül 2015].

URL-11, (2015), http://www.tubitak.gov.tr/tubitak_content_files/vizyon2023/csk/EK-4.pdf, [Erişim 24 Eylül 2015].

URL-12, (2016), http://www.marka.org.tr/uploads/files/ppkb/Kocaeli_At\%C4\%B1k_Envanteri.pdf, [Erișim 26 Temmuz 2016].

URL-13, (2015), http://www.kocaeligazetesi.com.tr/izmitte-bir-gunde-cikan-cop-miktari-638785h.htm, [Erişim 24 Eylül 2015].

URL-14, (2016), http://www.bizimkocaeli.com/haber/guncel/izmitin-copleri-icin-rekor-ihale/113954.html, [Erișim 26 Temmuz 2016].

URL-15, (2015), http://www.tuik.gov.tr/ilGostergeleri/iller/KOCAELI.pdf, [Erişim 24 Eylül 2015].

URL-16, (2016), http://www.haberturk.com/ekonomi/enerji/haber/853295-yeni-binalarda-bunu-yapmak-zorunlu-olacak, [Erişim 04 Ağustos 2016].

URL-17, (2016), http://www.imo.org.tr/resimler/ekutuphane/pdf/12243.pdf, [Erișim 04 Ağustos 2016].

Yenice M., Doğruparmak Ş.Ç., Durmuşoğlu E., (2009), Kocaeli ili katı atık karakterizasyonu, Türkiye'de Katı Atık Yönetimi Sempozyumu, 15-17 Haziran, YTÜ, İstanbul.

Yıldız S., Döker M.F., (2016), İzmit şehrinin nüfus gelişimi, İstanbul Üniversitesi Edebiyat Fakültesi Coğrafya Dergisi, 32(2016), 3347. 